[Agr. Biol. Chem., Vol. 34, No. 9, p. 1393 1401, 1970]

\title{
Syntheses and Biological Activities of New Plant Growth Inhibitors Structurally Related to Abscisic Acid
}

\author{
Part I
}

\author{
By Saburo TAmura and Minoru NAGAO \\ Department of Agricultural Chemistry, The University of Tokyo, Bunkyo-ku, Tokyo \\ Received February 24, 1970
}

\begin{abstract}
Several analogs of abscisic acid (ABA) were prepared and their biological activities were assayed. Among the compounds tested, 5-(1, 2-epoxy-2, 6, 6-trimethyl-1-cyclohexyl)-, 5-(1-hydroxy-2, 6, 6-trimethyl-2-cyclohexen-1-yl)-and 5-(1-hydroxy-2-methylene-6, 6-dimethyl1-cyclohexyl)-3-methyl-cis, trans-2, 4-pentadienoic esters (V, IX, XXIII and XXV) were found to be potent plant growth inhibitors. Their activities were superior or comparable to that of $\mathrm{ABA}$.
\end{abstract}

Abscisic acid, (+)-5-(1-hydroxy-4-oxo-2, 6, 6-trimethyl - 2-cyclohexen-1 - yl) -3-methyl - cis, trans-2, 4-pentadienoic acid (ABA, I) was first isolated from young cotton fruits by Ohkuma et al. ${ }^{1 \prime}$ in 1963 as an abscission-accelerating substance. Its wide distribution in higher plants has been demonstrated by various workers. ${ }^{21}$ Further, its diverse physiological activities are being extensively investigated, but insufficient accessibility of samples retards rapid growth in both fundamental and practical studies on this compound.

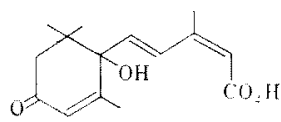

I

l) K. Ohkuma, J. L. Lyon, F. T. Addicott and O. E. Smith, Science, 142, 1592 (1963).

2) J. W. Cornforth, B. V. Milborrow, G. Ryback and P. F. Wareing, Nature, 205, 1269 (1965); J. W. Cornforth, B. V. Milborrow, G. Ryback, K. Rothwell and R. L. Wain, ibid., 211, 742 (1966); K. Koshimizu, H. Fukui, T. Mitsui and Y. Ogawa, Agr. Biol. Chem., 30, 941 (1966); Y. Isogai, T. Okamoto and Y. Komoda, Chem. Pharm. Bull., 15, 1256 (1967); T. Hashimoto and S. Tamura, Planta, 78, 89 (1968).
In 1965 Cornforth et al." succeeded in the synthesis of $A B A$ as the racemate. This procedure containing photooxidation of ethyl 5(2, 6, 6-trimethyl-1, 3-cyclohexadien-1-yl)-3-methyl-cis, trans-2, 4-pentadienoate and subsequent decomposition of the resulting epidioxide as intermediary steps was much complicated and resulted in poor yields even after the im-

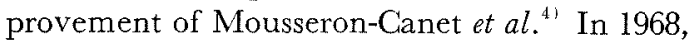
Roberts $e t$ al..$^{51}$ developed a three-step synthesis of the racemate which consists of $t$-butyl chromate oxidation of $a$-ionone, Wittig reaction of 4-(1-hydroxy-4-keto-2, 6, 6-trimethyl2-cyclohexen-1-yl)-3-buten-2-one and basic hydrolysis of the resulting ethyl abscisate. However, the over-all yield was not improved so much.

Recently, Asmundson et al. ${ }^{6 /}$ reported that

3) J. W. Cornforth, B. V. Milborrow and G. Ryback, Nature, 206, 715 (1965).

4) M. Mousseron-Canet, J. C. Mani, J. P. Dalle, and J. L. Olive, Bull. Soc. Chim. Fr, 1966, 3874.

5) D. L. Roberts, R. A. Heckman, B. P. Hege and S. A. Bellin, J. Org. Chem., 33, 3566 (1968).

6) C. M. Asmundson, R. Ingersoll, O. E. Smith and J. Kumamoto, Abstr. 155th Nat. Meet., Am. Chem. Soc., Div. of Agr. \& Food Chem., San Francisco, April I 5, 1968, p. 15. 


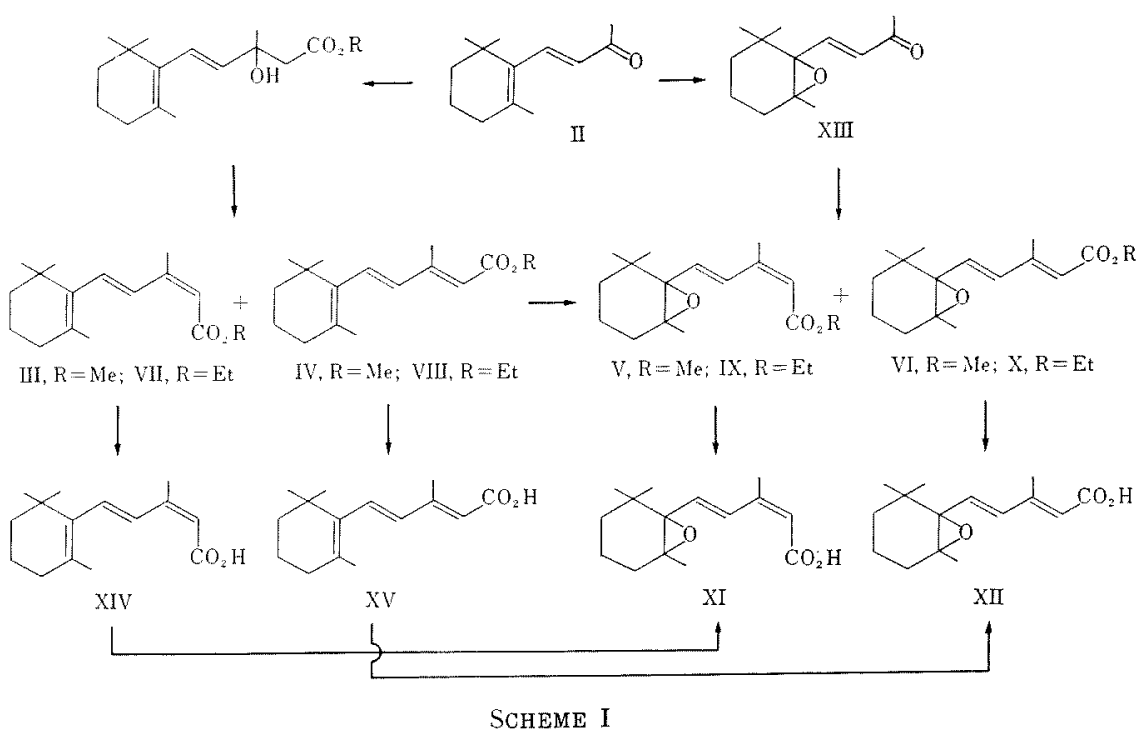

cis, trans-2, 4- $\alpha$-ionylideneacetic acid (XIV) was almost as active as ABA in a cotton bioassay as well as in other tests. They suggested that this compound may be a precursor of ABA.

In the course of our study to examine structure-activity relationships and, further, to find new plant growth regulators among synthetic analogs of ABA, we noticed that esters of 5-(1, 2-epoxy-2, 6, 6-trimethyl-1-cyclohexyl)-, 5-(1-hydroxy-2, 6, 6-trimethyl-2-cyclohexen-1yl)- and 5-(1-hydroxy-2-methylene-6, 6-dimethyl-1-cyclohexyl)-3-methyl-cis, trans-2, 4-pentadienoic acids possess marked biological activities superior or comparable to that of the $\mathrm{ABA}$ racemate, as preliminarily reported in the previous paper. ${ }^{71}$ Here we wish to describe syntheses and activities of these compounds together with several related substances in detail.

At first a mixture of methyl cis, trans- and trans, trans-2, 4- $\beta$-ionylideneacetates (III and IV) obtained from $\beta$-ionone (II) via the 3-

7) S. Tamura and M. Nagao, Agr. Biol. Chem., 33, 296, 1357 (1969); Planta, 85, 209 (1969). hydroxy ester ${ }^{8}$ was treated with perbenzoic acid in chloroform. The resulting methyl 5(1, 2-epoxy-2, 6, 6-trimethyl-1-cyclohexyl)-3methyl-cis, trans-2, 4-pentadienoate $(\mathrm{V})$ and its trans, trans isomer (VI) were separated from each other by silicic acid column chromatography using hexane-benzene mixtures. Epoxidation of $\beta$-ionylideneacetates could be also accomplished with air in the following way. A mixture of ethyl $\beta$-ionylideneacetates (VII and VIII) dissolved in ethyl acetate was poured onto kieselguhr and stirred up. After evaporation of the solvent, the powdery mixture was kept at room temperature for a week with occasional agitation and then extracted with ethyl acetate. The extract was evaporated and applied to chromatography to give ethyl 5-(1, 2-epoxy-2, 6, 6-trimethyl-1cyclohexyl)-3-methyl-2, 4-pentadienoates (IX and $\mathrm{X}$ ) in the manner similar to that men. tioned above. However, the air oxidation accompanied formation of various unidentified

8) P. Karrer, H. Salomon, R. Morf and O. Walker, Helv. Chim. Acta, 15, 878 (1932); W. G. Young, L. J. Andrews and S. J. Cristol, J. Am. Chem. Soc., 66, 520 (1944). 
byproducts, resulting in the lower yield of the desired epoxy esters. Further, the epoxy esters were obtainable through an alternate route via epoxy- $\beta$-ionone (XIII) which was prepared by epoxidation of $\beta$-ionone (II). ${ }^{91}$ The Wittig reaction between XIII and carbomethoxymethylenetriphenylphosphorane gave approximately equal amounts of $\mathrm{V}$ and VI. These procedures are illustrated in Scheme 1.

On hydrolysis with alcoholic potassium hydroxide at room temperature, each epoxy ester afforded the corresponding free acid (XI and XII). Both acids were also synthesized individually by epoxidation with perbenzoic acid of cis, trans- and trans, trans- $\beta$-ionylideneacetic acids (XIV and XV) which were prepared by saponification of a mixture of $\beta$ ionylideneacetates and subsequent fractional crystallization according to the method of Robeson et al. ${ }^{101}$

When $\mathrm{V}$ or VI was treated with sulfuric acid in aqueous methanol at room temperature, the epoxide ring of the ester was easily split to give the corresponding 1, 2-glycol, methyl 5-(1, 2-dihydroxy-2, 6, 6-trimethyl-1-cyclohexyl)-3-methyl-cis, trans-2, 4-pentadienoate (XVI) or its trans, trans isomer (XVII). On treatment with methanolic potassium hydroxide at room temperature, the esters XVI and XVII yielded free acids (XVIII and XIX), respectively.

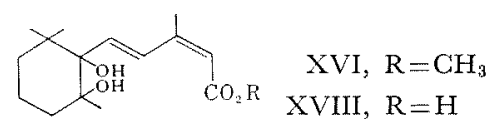

All attempts to eliminate the hydroxyl at $\mathrm{C}-2$ of the glycol ester XVI to give methyl 5-(1-hydroxy-2, 6, 6-trimethyl-2-cyclohexen-1yl)-3-methyl-cis, trans-2, 4-pentadienoate (XX-

9) Y. R. Naves, O. Schwarzkopf and A. D. Lewis, Helv. Chim. Acta, 30, 880 (1947).

10) C. D. Robeson, J. D. Cawley, L. Weisler, M.H. Stern, C. C. Eddinger and A. J. Chechak, J. Am. Chem. Soc., 77, 4111 (1955).

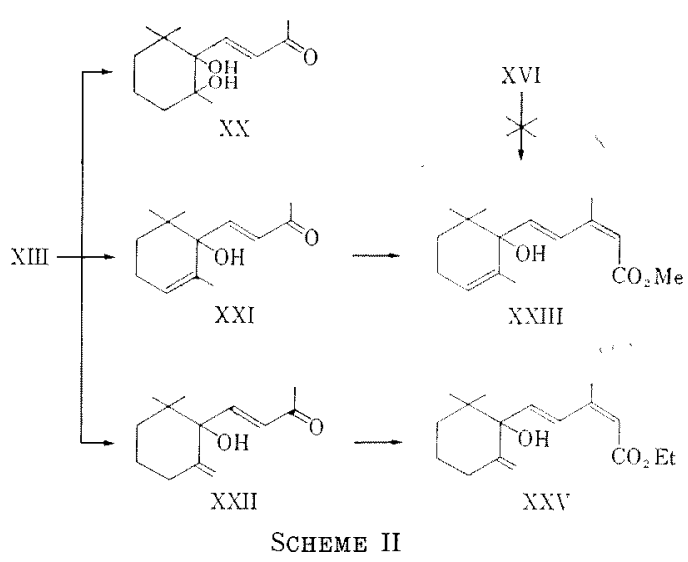

III), which corresponds to methyl deoxoabscisate, were unsuccessful. However, XXIII could be obtained together with its cis, trans isomer (XXIV) by the Wittig reaction of 4(1-hydroxy-2, 6, 6-trimethyl-2-cyclohexen-1-yl)3-buten-2-one (XXI) with carbomethoxymethylenetriphenylphosphorane and subsequent purification on thin-layer chromatography (TLG) using benzene-ethyl acetate $(9: 1)$, as shown in Scheme II. To prepare XXI epoxy$\beta$-ionone (XIII) was treated with dilute sulfuric or perchloric acid according to the procedure disclosed in the US patent. ${ }^{\text {II }}$ After removal of the crystals of the resulting 4-(1, 2-dihydroxy-2, 6, 6-trimethyl-1-cyclohexyl)-3buten-2-one $(\mathrm{XX})$, the reaction product was applied to silicic acid column chromatography. Elution with hexane-benzene $(1: 1)$ unexpectedly gave 4-(1-hydroxy-2-methylene-6, 6-dimethyl-1-cyclohexyl)-3-buten-2-one (XXII), an isomer of XXI containing an exomethylene at $\mathrm{C}-2$ of the ring, in addition to XXI. Then XXII was converted into ethyl 5-(1-hydroxy2-methylene-6, 6-dimethyl-1-cyclohexyl)-3-methyl-2, 4-pentadienoates (XXV and XXVI) by the Wittig reaction. Quite recently, Dalle $e t$ al. ${ }^{12}$ reported the synthesis of the methyl

11) D. L. Roberts, US Patent 3400158 (1968) [C.A., 69, 9085 (1968)].

12) J.P. Dalle, M. Mousseron-Canet and J.C. Mani, Bull. Soc. Chim. Fr., 1969, 232. 
esters corresponding to XXV and XXVI by the photooxidation of III and IV, though the preparation was not intended to evaluate biological activity.

Ethyl 5-(1-hydroxy-2, 6, 6-trimethyl-1-cyclohexyl)-3-methyl-2, 4-pentadienoates (XXVIII and XXIX) containing no double bond in the cyclohexyl moiety were prepared as illustrated in Scheme III. $\beta$-Ionone (II) was converted into ethylene ketal, which was epoxidized with perbenzoic acid. The reaction product, without further purification, was treated with a large excess of lithium aluminum hydride in tetrahydrofuran and subsequently acidified with dilute sulfuric acid to give 4-(1-hydroxy2 , 6, 6-trimethyl-1-cyclohexyl)-3-buten-2-one (XXVII). The ketone XXVII was then subjected to the Wittig reaction resulting in the formation of the desired XXVIII and XXIX.

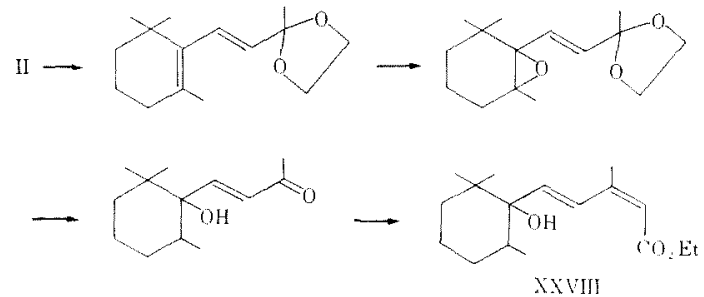

SCHEME III

As the ethyl homolog of $\mathrm{V}$ at $\mathrm{C}-3$ of the side chain, methyl 5-(1, 2-epoxy-2, 6, 6-trimethyl-1-cyclohexyl)-3-ethyl-cis, trans-2, 4-pentadienoate $(\mathrm{XXX})$ was synthesized in the way similar to that for $\mathrm{V}$ by subjecting $5-(2,6,6-$ trimethyl-1-cyclohexen-l-yl)-4-penten-3-one to the Wittig reaction followed by epoxidation with perbenzoic acid.

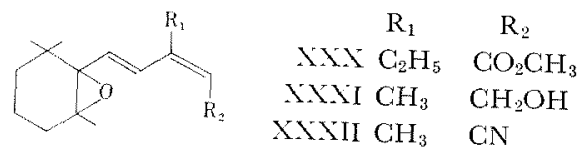

Finally, the analogs of $\mathrm{V}$ with respect to the functional groups attached to the terminus of the side chain were prepared in the following way. For the synthesis of $5-(1,2$ epoxy-2, 6, 6-trimethyl-1-cyclohexyl)-3-methylcis, trans-2, 4-pentadien-1-ol (XXXI), the pentadienoic ester $V$ was treated with an equimolar amount of lithium aluminum hydride in tetrahydrofuran at room temperature, and the reaction product was purified by TLC using benzene-ethyl acetate $(85: 15)$. 5- $(1,2$ Epoxy-2, 6, 6-trimethyl-1-cyclohexyl)-3-methyl2, 4-pentadienonitriles (XXXII and XXXIII) were prepared by the Wittig reaction between epoxy- $\beta$-ionone and cyanomethylenetriphenylphosphorane, followed by TLG using benzeneethyl acetate (93:7).

The biological activities of the ABA analogs thus obtained were tested on rice seedlings (Oryza sativa L., cv. "Koshijiwase") according to the method of Murakami. ${ }^{13)}$ As shown in

Table I. Effects of Abscisic ACID ANalogs ON GROWTH OF THE SECOND LEAF Sheath of RICE SEedling (cv. "Koshijiwase")

Control $=100 ; 38.0 \mathrm{~mm}$

\begin{tabular}{lccccccc} 
& \multicolumn{6}{c}{ Concentration (mg/liter) } \\
\cline { 2 - 8 } Compound & 50 & 25 & 12.5 & 6 & 3 & 1.5 \\
V & $-a)$ & - & - & - & 20.6 & 50.3 \\
VI & 72.4 & 75.6 & 82.1 & 83.0 & 87.8 & 95.1 \\
IX & - & - & - & - & 23.2 & 49.5 \\
XI & - & 22.1 & 43.4 & 67.8 & 75.6 & 80.1 \\
XII & 82.5 & 84.9 & 95.6 & 98.2 & 101.3 & 100.5 \\
XVI & 78.1 & 80.4 & 82.7 & 85.1 & 90.2 & 90.9 \\
XVIII & 85.3 & 86.2 & 88.6 & 94.1 & 93.9 & 94.5 \\
XXIII & - & - & - & - & 24.5 & 58.5 \\
XXIV & 98.1 & 97.3 & 99.6 & 101.4 & 100.7 & 102.8 \\
XXV & - & - & - & 45.2 & 86.8 & 95.5 \\
XXVI & 67.9 & 72.9 & 85.8 & 93.6 & 95.8 & 94.0 \\
XXVIII & 83.0 & 88.7 & 94.2 & 99.2 & 102.8 & 104.3 \\
XXIX & 85.5 & 90.5 & 96.1 & 102.3 & 109.5 & 105.1 \\
XXX & - & 56.5 & 78.6 & 81.0 & 91.3 & 94.4 \\
XXXI & 46.4 & 67.1 & 75.8 & 89.1 & 90.7 & 93.0 \\
XXXII & 100.2 & 108.3 & 108.7 & 102.0 & 100.6 & 103.1 \\
XXXIII & 91.3 & 100.5 & 103.2 & 101.6 & 104.3 & 102.7 \\
(土)-ABA & - & - & - & - & 37.4 & 71.9 \\
& & & & & &
\end{tabular}

a) Complete inhibition.

13) Y. Murakami, Bot. Mag. (Tokyo), 72, 36 (1959). 
Table I, 5-(1, 2-epoxy-2, 6, 6-trimethyl-1-cyclohexyl)-, 5-(1-hydroxy-2, 6, 6-trimethyl-2-cyclohexen-1-yl)- and 5-(1-hydroxy-2-methylene-6, 6-dimethyl-1-cyclohexyl)-3-methyl-cis, trans-2, 4-pentadienoic esters (V, IX, XXIII and XXV) completely inhibited elongation of the second leaf sheath even at concentrations of 6.0 and $12.5 \mathrm{mg} /$ liter, respectively, the efficacy being superior or comparable to that of the $\mathrm{ABA}$ racemate. On the contrary, 5-(1, 2-dihydroxy2,6,6-trimethyl-1-cyclohexyl)- and 5-(1-hydro$\mathrm{xy}-2,6,6$-trimethyl-1-cyclohexyl)-3-methyl-cis, trans-2, 4-pentadienoic esters (XVI and XXVIII) containing no $\mathrm{C}=\mathrm{C}$ double bond in the ring moiety scarcely showed any activity despite the presence of the hydroxyl group at $\mathrm{C}-1$. These suggest the following possibilities: 1) The ketone group contained in the ring of $\mathrm{ABA}$ molecule may not be required for the activity. 2) The unsaturated structure located at $\mathrm{C}-2$ of the ring may play an important role to exhibit biological effect. 3) The glycol ester XVI may not be dehydrated by plant tissues to form a double bond at C2 of the ring. 4) The compounds $V$ and IX may become active in plant tissues after the formation of such compounds as XXIII and $\mathrm{XXV}$ through the alternative ways illustrated in Scheme IV.

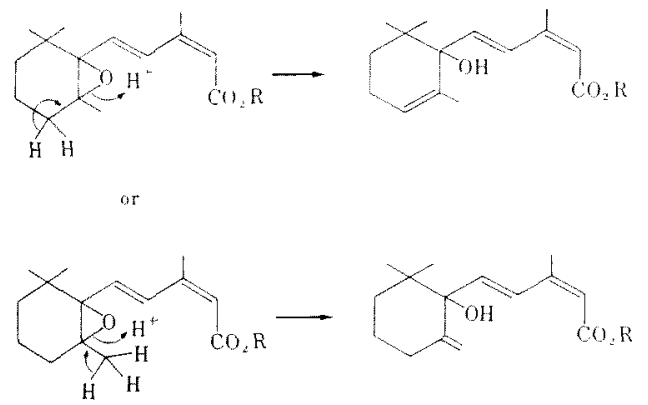

$$
\text { SCHEME IV }
$$

As expected, the inhibitory activities of the compounds VI, XII and XXIV with trans, trans-2, 4-pentadienoic residues were far inferior to those of the corresponding cis, trans isomers, in spite of the presence of epoxide group or $\mathrm{C}=\mathrm{C}$ double bond on the ring moiety.

As for the effects of the epoxide compounds, the free acid XI was markedly weaker than the esters $V$ and IX. Such a difference in activities has already been reported for $A B A$ and its methyl ester by Koshimizu et al.," who suggested that the higher toxicity of the ester on rice seedlings may be due to its easier penetration into the plants.

Concerning the structure-activity relationships in the side chain, the compound XXX, the ethyl homolog of $\mathrm{V}$ at $\mathrm{C}-3$, unexpectedly suppressed the growth of seedlings, though the activity was significantly weaker than that of $\mathrm{V}$ The pentadienol XXXI containing a hydroxymethyl group at the terminal part of the side chain showed only slight activity. Further, the substitution by a nitrile to give the compound XXXII almost nulified the inhibitory effect. This indicates that the presence of carboxyl or alkoxycarbonyl group is essential and that the nitrile group of XXXII is not easily hydrolyzed in the plant tissues.

Interaction between gibberellin $\mathrm{A}_{3}\left(\mathrm{GA}_{3}\right)$ and the epoxy ester IX was examined by simultaneous application of the both compounds to rice seedlings (dwarf cutivar "Kotake-tamanishiki") just after germination. As shown

TABLE II. INTERACTION OF COMPOUND IN WITH GibBerellin $\mathrm{A}_{3}$ IN Leaf Sheath Growth (Whole LENGTH) OF Rice SEedLings (cv. "Kotake-tamanishiki")

Control $=100 ; 41.9 \mathrm{~mm}$

\begin{tabular}{|c|c|c|c|c|c|}
\hline \multirow{2}{*}{$\begin{array}{l}\text { Compound IX } \\
\text { (mole/liter) }\end{array}$} & \multicolumn{5}{|c|}{$\mathrm{GA}_{3}$ (mole/liter) } \\
\hline & $10^{-4}$ & $10^{-5}$ & $10^{-6}$ & $10^{-7}$ & 0 \\
\hline $10^{-1}$ & 11.9 & 9.5 & 9.5 & 9.5 & 9.5 \\
\hline $2 \times 10^{-5}$ & 26.0 & 20.0 & 17.4 & 16.0 & I6. 1 \\
\hline $4 \times 10^{-6}$ & 75.2 & 77.4 & 61.1 & 49.0 & 48.6 \\
\hline $8 \times 10^{-1}$ & 200.0 & 162.6 & 126.5 & 93.3 & 91.7 \\
\hline 0 & 252.9 & 218.3 & 156.0 & 114.5 & $100^{a}$ \\
\hline
\end{tabular}


in Table II, the compound IX at the concentration of $1 \times 10^{-4} \mathrm{M}$ completely inhibited the stem elongation (whole length) caused by $\mathrm{GA}_{3}$ at the same concentration, and even at $4 \times 10^{-6} \mathrm{M}$ significantly counteracted the action of $\mathrm{GA}_{3}$ at $1 \times 10^{-4} \mathrm{M}$.

Finally, effects of the epoxy compounds $\mathrm{V}$ and XI on Avena coleoptile straight growth ${ }^{14}$ are assayed in the presence of IAA. As indicated in Fig. 1, both $\mathrm{V}$ and XI at a concentration of $50 \mathrm{mg} /$ liter completely counteracted the growth promotion caused by IAA at $1 \mathrm{mg} /$ liter. In the absence of IAA, they also inhibited the small amount of growth that occurred in the blank buffer. Thus the activities of the acid and ester on Avena coleoptile sections were comparable to each other.

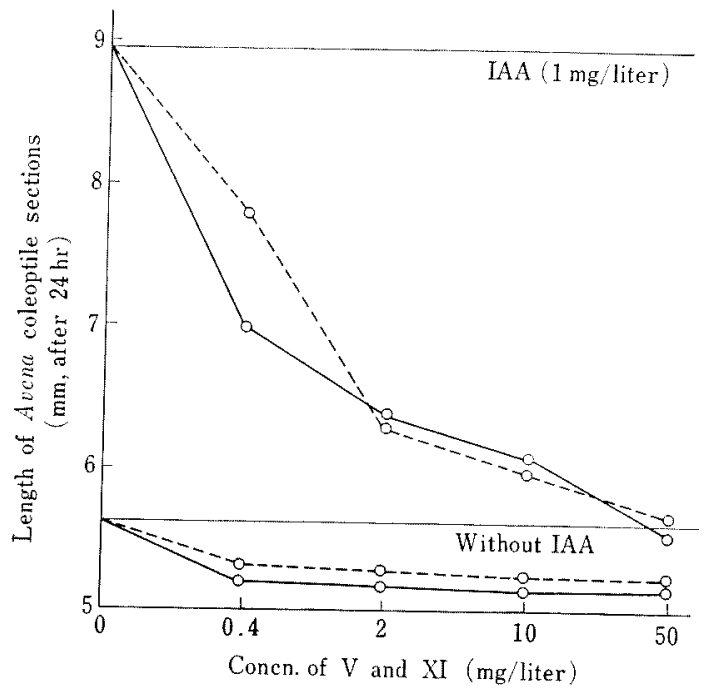

FIG. 1. Interaction of Compounds $V$ and XI with IAA on the Elongation of Avena Coleoptile Sections.

Points show average growth of 15 sections, initial length $5 \mathrm{~mm}$. Each Petri dish contained 20 $\mathrm{ml}$ of $2 \%$ sucrose with $1 \mathrm{mg} /$ liter IAA, buffered at $\mathrm{pH} 6.4$.

$\mathrm{O}-\mathrm{O} \mathrm{V}, \quad \mathrm{O}-\mathrm{O} \mathrm{XI}$

14) R. M. Muir, C. H. Hansch and A. H. Gallap, Plant Physiol., 24, 359 (1949).
It is worthy of note that new potent $A B A$ analogs, 5-(1, 2-epoxy-2, 6, 6-trimethyl-1-cyclohexyl)-, 5-(1-hydroxy-2, 6, 6-trimethyl-2-cyclohexen-1-yl)- and 5-(1-hydroxy-2-methylene-6, 6 dimethyl-1-cyclohexyl)-3-methyl-cis, trans-2, 4 pentadienoic esters, have been discovered through this study. Among them, the epoxy esters can be most easily synthesized starting from $\beta$-ionone and, therefore, they should be useful in studies on biological activities of ABA and its analogs.

\section{EXPERIMENTAL}

Melting points are uncorrected. The IR spectra were determined with a JASCO $\mathrm{KCl}$ spectrophotometer. The UV spectra were taken with a Cary-DM spectrometer. The NMR spectra were recorded on a JNM- $4 \mathrm{H}-100$ apparatus with tetramethylsilane as an internal standard.

5-(1,2-Epoxy-2,6, 6-trimethyl-1-cyclohexyl)-3-methyl-2,4pentadienoic esters $(V, V I, I X$ and $X)$.

Method A. A mixture (3.2 g) of methyl cis, transand trans, trans-2, 4- $\beta$-ionylideneacetates (III and IV) was dissolved in chloroform $(10 \mathrm{ml})$, to which perbenzoic acid $(2.2 \mathrm{~g})$ in the same solvent $(30 \mathrm{ml})$ was added dropwise at $0^{\circ} \mathrm{C}$. After standing overnight at $5^{\circ} \mathrm{C}$, the reaction mixture was washed with aqueous sodium bicarbonate and water, successively. After evaporation of the solvent, the residual syrup $(3.1 \mathrm{~g})$ was applied to adsorption chromatography on a column of silicic acid (Mallinckrodt, $30 \mathrm{~g}$ ), which was eluted with hexane at first to remove the unchanged III and IV and then with hexane-benzene mixtures increasing the share of the latter. Elution with a 9:1 mixture afforded the trans, trans epoxy ester VI $(1.0 \mathrm{~g})$ and with a $7: 3$ mixture the cis, trans isomer $\mathrm{V}(0.9 \mathrm{~g})$.

$\mathrm{V}$ Liquid. UV $\lambda_{\max }^{\mathrm{EtOH}} \mathrm{m} \mu(\varepsilon): 267 \quad(18,600)$. IR $\nu_{\max }^{\text {Film }} \mathrm{cm}^{-1}: 2930,1710,1632,1602,1230,1160$. NMR (in $\mathrm{CDCl}_{3}$ ) $0: 0.96(3 \mathrm{H}), 1.09(3 \mathrm{H}), 1.17(3 \mathrm{H}), 2.01(3$ $\mathrm{H}), 3.60(3 \mathrm{H}), 5.70(\mathrm{lH}), 6.25(1 \mathrm{H}), 7.61(1 \mathrm{H})$. Found: C, 72.50; H, 9.10. Calcd. for $\mathrm{C}_{16} \mathrm{H}_{24} \mathrm{O}_{3} ; \mathrm{C}, 72.69$; H, 9.15\%. VI, Liquid. UV $\lambda_{\max }^{\mathrm{EtOH}} \mathrm{m} \mu(\varepsilon): 267(25,670)$. IR $\nu_{\max }^{\text {Film }} \mathrm{cm}^{-1} ; 2930,1710,1632,1613,1232,1160$. NMR (in $\left.\mathrm{CDCl}_{3}\right) \delta: 0.93(3 \mathrm{H}), 1.12(3 \mathrm{H}), 1.14(3 \mathrm{H})$, $2.31(3 \mathrm{H}), 3.60(3 \mathrm{H}), 5.82(1 \mathrm{H}), 6.32(2 \mathrm{H})$. Found: $\mathrm{C}$, 72.80; $\mathrm{H}, 9.20$. Calcd. for $\mathrm{C}_{16} \mathrm{H}_{24} \mathrm{O}_{3}: \mathrm{C}, 72.69 ; \mathrm{H}$, $9.15 \%$. 
Method $B$. A mixture $(7.0 \mathrm{~g})$ of ethyl cis, transand trans, trans- $\beta$-ionylideneacetates (VII and VIII) dissolved in ethyl acetate $(20 \mathrm{ml})$ was added to kieselguhr (Hyflo Super-Cel, 7.0 g) and stirred up. After evaporation of the solvent, the powdery mixture was kept at room temperature for a week with occasional agitation and then extracted with ethyl acetate. Removal of the solvent gave an oily residue $(6.0 \mathrm{~g})$, which was chromatographed in the manner similar to that in Method A to afford the cis, trans epoxy ester IX $(1.5 \mathrm{~g})$ and its trans, trans isomer $\mathrm{X}(1.4 \mathrm{~g})$. IX, Liquid. UV $\lambda_{\max }^{\mathrm{EtoH}} \mathrm{m} \mu(\varepsilon): 268(17,560)$. IR $\nu_{\max }^{\mathrm{Fim}} \mathrm{cm}^{-1}: 2930,1710,1632,1602,1230.1160$. NMR (in $\mathrm{CDCl}_{3}$ ) oे: $0.98(3 \mathrm{H}), 1.10(3 \mathrm{H}), 1.18(3 \mathrm{H}), 1.28$ $(3 \mathrm{H}), 2.01(3 \mathrm{H}), 4.18(2 \mathrm{H}), 5.70(1 \mathrm{H}), 6.25(1 \mathrm{H}), 7.62$ (1H). Found: $\mathrm{C}, 73.31 ; \mathrm{H}, 9.42$. Calcd. for $\mathrm{C}_{17} \mathrm{H}_{26}$ $\mathrm{O}_{3}: \mathrm{C}, 73.34 ; \mathrm{H}, 9.41 \% . \mathrm{X}$, Liquid. UV $\lambda_{\max }^{\mathrm{EtOH}}$ $\mathrm{m} \mu(\varepsilon): 268(26,000) . \quad \mathrm{IR} \nu_{\max }^{\mathrm{Film}} \mathrm{cm}^{-1}: 2930,1710,1632$, $1613,1232,1160$. NMR (in $\left.\mathrm{CDCl}_{3}\right) \delta: 0.93(3 \mathrm{H})$, $1.12(3 \mathrm{H}), 1.15(3 \mathrm{H}), 1.80(3 \mathrm{H}), 2.30(3 \mathrm{H}), 4.20(2 \mathrm{H})$, $5.81(1 \mathrm{H}), 6.32(2 \mathrm{H})$. Found: $\mathrm{C}, 73.15 ; \mathrm{H}, 9.56$. Calcd. for $\mathrm{C}_{17} \mathrm{H}_{26} \mathrm{O}_{3}: \mathrm{C}, 73.34 ; \mathrm{H}, 9.41 \%$.

Method C. A mixture of epoxy- $\beta$-ionone $(0.7 \mathrm{~g})$ and carbomethoxymethylenetriphenylphosphorane ( 1.5 g) was heated at $150 \sim 170^{\circ} \mathrm{C}$ for $2 \mathrm{hr}$. The cooled mixture was triturated with hexane, filtered to remove the triphenylphosphine oxide and then subjected to chromatography as in the case of Method A to give $\mathrm{V}(0.3 \mathrm{~g})$ and $\mathrm{VI}(0.3 \mathrm{~g})$.

5-(1, 2-Epoxy-2, 6, 6-trimethyl-1-cyclohexyl)-3-methyl-2, 4-pentadienoic acids (XI and $X I I)$.

Method A. The epoxy ester V or VI was treated with 10\%' ethanolic potassium hydroxide at room temperature for $24 \mathrm{hr}$. The reaction mixture was diluted with water and extracted with ether. The aqueous portion was acidified and extracted with ether. Evaporation of the solvent afforded the corresponding free cis, trans acid XI or trans, trans isomer $\mathrm{XII}$ in approximately $85 \%$ yield.

XI. Mp $146 \sim 147^{\circ} \mathrm{C}$ (from acetonitrile or benzene). UV $\lambda_{\max }^{\text {EtOH }} \mathrm{m} \mu(\varepsilon): 265(20,500) . \quad$ IR $\nu_{\max }^{\mathrm{Nujol}} \mathrm{cm}^{-1}$ : $1675,1630,1600,1290,1260$. NMR (in $\left.\mathrm{CDCl}_{3}\right) \delta:$ $1.00(3 \mathrm{H}), 1.13(3 \mathrm{H}), 1.21(3 \mathrm{H}), 2.04(3 \mathrm{H}), 5.72(1 \mathrm{H})$, $6.32(1 \mathrm{H}), 7.62(1 \mathrm{H})$. Found: $\mathrm{C}, 71.83 ; \mathrm{H}, 8.61$. Calcd. for $\mathrm{C}_{15} \mathrm{H}_{22} \mathrm{O}_{3}: \mathrm{C}, 71.97 ; \mathrm{H}, 8.86 \%$.

XII. Mp 105 107 ${ }^{\circ} \mathrm{C}$ (from benzene). UV $\lambda_{\mathrm{max}}^{\mathrm{EtOH}} \mathrm{m} \mu(\varepsilon)$ : $264(26,240)$. IR $\nu_{\max }^{\mathrm{Nu} \text { jol }} \mathrm{cm}^{-1}: 1680,1630,1610,1250$,
1190. NMR (in $\mathrm{CDCl}_{3}$ ) $\delta: 0.97(3 \mathrm{H}), 1.15(3 \mathrm{H}), 1.18$ $(3 \mathrm{H}), 2.32(3 \mathrm{H}), 5.83(1 \mathrm{H}), 6.37(2 \mathrm{H})$. Found: C, 71.87 ; $\mathrm{H}, 9.09$. Calcd. for $\mathrm{C}_{15} \mathrm{H}_{22} \mathrm{O}_{3}: \mathrm{C}, 71.97 ; \mathrm{H}, 8.86 \%$.

Method B. To a solution of cis, trans- or trans, trans- $\beta$-ionylideneacetic acid (XIV or XV, $600 \mathrm{mg}$ ) in chloroform $(8 \mathrm{ml})$ was added dropwise perbenzoic acid $(400 \mathrm{mg})$ in the same solvent $(7 \mathrm{ml})$ at $0^{\circ} \mathrm{C}$. After standing overnight at $5^{\circ} \mathrm{C}$, the reaction mixture was evaporated, and the residual solid was recrystallized from benzene to give the corresponding epoxy acid $\mathrm{XI}$ or XII in approximately 7096 yield.

Methyl 5-(1,2-dihydroxy-2,6,6-trimethyl-1-cyclohexyl)3-methyl-2, 4-pentadienoates (XVI and XVII). The epoxy ester V or VI $(500 \mathrm{mg})$ was treated with 20,0 aqueous sulfuric acid $(1 \mathrm{ml})$ in ethanol $(4 \mathrm{ml})$ at room temperature for $48 \mathrm{hr}$. The reaction mixture was. diluted with water and extracted with ether. The extract was washed with water and evaporated to give the corresponding cis, trans glycol ester XVI or trans, trans isomer XVII $(200 \mathrm{~g})$.

XVI. Mp $151 \sim 153^{\circ} \mathrm{C}$ (from benzene). UV $\lambda_{\max }^{\mathrm{EtoH}}$ $\mathrm{m} \mu(\varepsilon): 272(20,400)$. IR $\nu_{\max }^{\mathrm{Nu} j o 1} \mathrm{~cm}^{-1}: 3520,1693,1635$, $1600,1245,1175$. NMR (in $\mathrm{CDCl}_{3}$ ) $\delta: 0.88(3 \mathrm{H}), 1.17$ $(3 \mathrm{H}), 1.22(3 \mathrm{H}), 2.06(3 \mathrm{H}), 3.60(3 \mathrm{H}), 5.71(1 \mathrm{H}), 6.67$ $(1 \mathrm{H}), 7.77(1 \mathrm{H})$. Found: C, 68.00; H, 9.20. Calcd. for $\mathrm{C}_{16} \mathrm{H}_{26} \mathrm{O}_{4}: \mathrm{C}, 68.05 ; \mathrm{H}, 9.28 \%$. XVII. Mp $114 \sim$ $116^{\circ} \mathrm{C}$ (from acetonitrile or water). UV $\lambda_{\max }^{\mathrm{EtOH}} \mathrm{m} \mu(\varepsilon)$ : 271(25,400). IR $\nu_{\mathrm{max}}^{\mathrm{Nujol}} \mathrm{cm}^{-1}: 3570,3520,1695,1635$, $1612,1440,1255,1180,990$. Found: $\mathrm{C}, 68.30 ; \mathrm{H}$. 9.41. Calcd. for $\mathrm{C}_{16} \mathrm{H}_{26} \mathrm{O}_{4}: \mathrm{C}, 68.05 ; \mathrm{H}, 9.28 \%$.

5-(1,2-Dihydroxy-2, 6,6-trimethyl-1-cyclohexyl)-3-methyl2,4-pentadienoic acids (XVIII and XIX). The glycol ester XVI or XVII $(150 \mathrm{mg})$ was hydrolyzed with $10 \%$ methanolic potassium hydroxide at room temperature for $24 \mathrm{br}$ and subsequently treated in the way similar to that for $\mathrm{V}$ or $\mathrm{VI}$ to give the corresponding free cis, trans acid XVIII or trans, trans isomer XIX $(60 \mathrm{mg})$.

XVIII. Mp $155 \sim 156^{\circ} \mathrm{C}$ (from benzene). UV $\lambda_{\mathrm{max}}^{\mathrm{EtoH}}$ $\mathrm{m} \mu(\varepsilon): 269(18,560) . \quad$ IR $\nu_{\max }^{\mathrm{Nujol}} \mathrm{cm}^{-1}: 3560,3500,1665$, $1625,1600,1260,1135,990$. NMR (in $\mathrm{CD}_{3} \mathrm{COCD}_{3}$ ) $\delta: 0.88(3 \mathrm{H}), 1.17(3 \mathrm{H}), 1.27(3 \mathrm{H}), 2.08(3 \mathrm{H}), 5.70(1 \mathrm{H})$, $6.85(1 \mathrm{H}), 7.85(\mathrm{HH})$. Found: C, 66.85; H, 8.79. Calcd. for $\mathrm{C}_{15} \mathrm{H}_{24} \mathrm{O}_{4}: \mathrm{C}, 67.13 ; \mathrm{H}, 9.02 \%$. XIX. Mp $213 \sim 215^{\circ} \mathrm{C}$ (from acetonitrile). UV $\lambda_{\max }^{\mathrm{EtOH}} \mathrm{m} \mu(\varepsilon): 268$ $(25,600) . \quad I R \quad \nu_{\max }^{\mathrm{Nujol}} \mathrm{cm}^{-1}: 3520,3480,1690,1635$, 1600. NMR (in $\mathrm{CD}_{3} \mathrm{COCD}_{3}$ ) $0: 0.87(3 \mathrm{H}), 1.15(3 \mathrm{H})$, 
$1.30(3 \mathrm{H}), 2.39(3 \mathrm{H}), 5.82(\mathrm{IH}), 6.50(\mathrm{HH}), 6.88(1 \mathrm{H})$. Found: $\mathrm{C}, 66.90 ; \mathrm{H}, 8.97$. Calcd. for $\mathrm{C}_{15} \mathrm{H}_{24} \mathrm{O}_{4}$ : C, $67.13 ; \mathrm{H}, 9.02 \%$.

4-(1-Hydroxy-2, 6, 6-trimethyl-2-cyclohexen-1-yl)-3-buten2-one $(X X I)$ and 4-(1-hydroxy-2-methylene-6, 6-dimethyl-1-

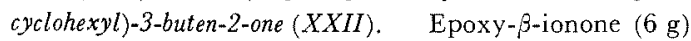
was added either to a mixture of $20 \%$ aqueous sulfuric acid $(8 \mathrm{ml})$ and ethanol $(22 \mathrm{ml})^{11}$ or to that of $30 \%$ aqueous perchloric acid $(3 \mathrm{ml})$ and tetrahydrofuran $(50 \mathrm{ml})$ and kept at $30^{\circ} \mathrm{C}$ for $24 \mathrm{hr}$. After addition of water, the reaction mixture was extracted with ether. Evaporation of the extract gave crystals (4g) of 4-(1, 2-dihydroxy-2,6, 6-trimethyl-1-cyclohexyl)3-buten-2-one $(\mathrm{XX})$, which was removed by filtration. The filtrate was applied to silicic acid column chromatography. Elution with hexane-benzene $(1: 1, v / v)$ gave a pale yellow wax $(70 \mathrm{mg})$ melting around $70^{\circ} \mathrm{C}$ and XXI (100 mg), $\mathrm{mp} 82^{\circ} \mathrm{G}$ (lit. ${ }^{11} 82 \sim 83^{\circ} \mathrm{G}$ ), successively. The former was identified as 4-(1-hydroxy2-methylene-6, 6-dimethyl-I-cyclohexyl)-3-buten-2-one (XXII) on the basis of spectral data. IR $\nu_{\max }^{\mathrm{Nujol}} \mathrm{cm}^{-1}$ : $3500,3450,1680,1645,1270,1145,990,920$. NMR (in $\mathrm{CDCl}_{3}$ ) $\delta: 0.98(3 \mathrm{H}), 1.00(3 \mathrm{H}), 2.32(3 \mathrm{H}), 4.93$ $(2 \mathrm{H}), 6.51(1 \mathrm{H}), 7.31(1 \mathrm{H})$. XXII was employed for the subsequent reaction without further purification.

Methyl 5-(1-hydroxy-2, 6, 6-trimethyl-2-cyclohexen-1-yl)3-methyl-2, 4-pentadienoates (XXIII and XXIV). A mixture of the ketone XXI (80 $\mathrm{mg})$ and two molar equivalents $(280 \mathrm{mg}$ ) of carbomethoxymethylenetriphenylphosphorane was heated at $150^{\circ} \mathrm{C}$ for $1.5 \mathrm{hr}$. After cooling, the reaction mixture was treated with hexane, and triphenylphosphine oxide was removed by filtration. The filtrate was evaporated, and the residue was applied onto thin layers of silicic acid, which were developed with benzene-ethyl acetate $(9: 1, \mathrm{v} / \mathrm{v})$ to afford methyl 5-(1-hydroxy-2, 6, 6-trimethyl-2-cyclohexen-1-yl)-3-methyl-cis, trans-2, 4-pentadienoate (XXIII) in $30 \%$ yield and its trans, trans isomer (XXIV) in $33 \%$ yield.

XXIII, Liquid. UV $\lambda_{\min }^{\mathrm{EtOH}} \mathrm{m} \mu(\varepsilon): 268(11,500)$. IR $\nu_{\max }^{\text {Film }} \mathrm{cm}^{-1}: 3530,1715,1638,1605,1240,1165,1045$, 990. NMR (in $\mathrm{CDCl}_{3}$ ) $\delta: 0.90(3 \mathrm{H}), 1.00(3 \mathrm{H}), 1.62$ $(3 \mathrm{H}), 2.00(3 \mathrm{H}), 3.65(3 \mathrm{H}), 5.50(1 \mathrm{H}), 5.63(1 \mathrm{H}), 6.09$ $(1 \mathrm{H}), 7.66(1 \mathrm{H})$. Found: C, 72.58; H, 9.15. Calcd. for $\mathrm{C}_{16} \mathrm{H}_{24} \mathrm{O}: \mathrm{C}, 72.72 ; \mathrm{H}, 9.15 \%$ XXIV, Liquid. IR $\nu_{\max }^{\text {Film }} \mathrm{cm}^{-1}: 3530,1715,1620,1440,1245,1165$. Found: $\mathrm{C}, 72.5 \mathrm{l} ; \mathrm{H}, 9.10$. Calcd. for $\mathrm{C}_{16} \mathrm{H}_{24} \mathrm{O}: \mathrm{C}$, $72.72 ; \mathrm{H}, 9.15 \%$.
Ethyl 5-(1-hydroxy-2-methylene-6, 6-dimethyl-1-cyclohex$y l$ )-3-methyl-2, 4-pentadienoates ( $X X V$ and $X X V I$ ). Similarly, the ketone XXII was subjected to the Wittig reaction to give ethyl 5-(1-hydroxy-2-methylene-6, 6dimethyl-1-cyclohexyl)-3-methyl-cis, trans-2, 4-pentadjenoate (XXV) in $330^{\circ}$ yield and its trans, trans isomer (XXVI) in $34 \%$.

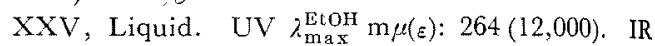
$\nu_{\max }^{\mathrm{Film}} \mathrm{cm}^{-1}: 3500,1710,1635,1603,1230,1160,1055$, 990,890 . NMR (in $\mathrm{CDCl}_{3}$ ) $\delta: 1.00(6 \mathrm{H}), 1.37(3 \mathrm{H})$, $2.10(3 \mathrm{H}), 4.22(2 \mathrm{H}), 4.98(2 \mathrm{H}), 5.77(1 \mathrm{H}), 6.63(1 \mathrm{H})$, 7.92(1H). Found: C, 73.30; H, 9.34. Calcd. for $\mathrm{C}_{17} \mathrm{H}_{26} \mathrm{O}_{3}$ : C, 73.34; H, 9.41\%. XXVI, Liquid. IR $\nu_{\max }^{F i l m} \mathrm{~cm}^{-1}: 3520,1710,1615,1240,1160,1050,985$. Found: $\mathrm{C}, 73.28 ; \mathrm{H}, 9.25$. Calcd. for $\mathrm{C}_{17} \mathrm{H}_{26} \mathrm{O}_{3}$ : C, 73.34, H, 9.419.

Ethyl 5-(1-hydroxy-2, 6, 6-trimethyl-1-cyclohexyl)-3methyl-2, 4-pentadienoates (XXVIII and XXIX). $\beta$ Ionone was converted into the ethylene ketal by the usual way. The ketal ( $3 \mathrm{~g}$ ) dissolved in chloroform $(5 \mathrm{ml})$ was treated with perbenzoic acid $(2 \mathrm{~g})$ in the same solvent $(30 \mathrm{ml})$ at $0^{\circ} \mathrm{C}$. After standing overnight at $5^{\circ} \mathrm{C}$, the chloroform solution was washed with sodium bicarbonate and water successively. The solvent was evaporated and the residue, without further purification, was treated with lithium aluminum hydride $(500 \mathrm{mg})$ in tetrahydrofuran $(50 \mathrm{ml})$ for $10 \mathrm{hr}$ under reflux. To the reaction mixture was added water and sulfuric acid successively, and the solution was extracted with ether. After evaporation of the solvent, the residue was subjected to silicic acid chromatography.

Elution with hexane-benzen $(1: 1, v / v)$ gave 4 -(lhydroxy-2,6,6-trimethyl-1-cyclohexyl)-3-buten-2-one (XXVII, $700 \mathrm{mg}$ ) as colorless crystals. Mp $83 \sim 85^{\circ} \mathrm{C}$ (from hexane). IR $\nu_{\max }^{\mathrm{Nujol}} \mathrm{cm}^{-1}: 3540,1680,1658$, I635, 1295, 1275, 1168, 1030, 1000, 955. NMR (in $\mathrm{CDCl}_{3}$ ) oे: $0.75(3 \mathrm{H}), 0.85(3 \mathrm{H}), \quad 1.07(3 \mathrm{H}), \quad 2.23(3 \mathrm{H}), \quad 6.33$ $(1 \mathrm{H}), 6.80(1 \mathrm{H})$.

Subsequently, XXVII was subjected to the Wittig reaction as in the case of XXI to give ethyl 5-(1hydroxy-2, 6, 6-trimethyl-1-cyclohexyl)-3-methyl-cis, trans-2, 4-pentadienoate (XXVIII) in $28 \%$ and its trans, trans isomer (XXIX) in $32 \%$.

XXVIII, Liquid. UV $\lambda_{\max }^{\mathrm{EtOH}} \mathrm{m} \mu(\varepsilon): 270(20,000)$. IR $\nu_{\max }^{\mathrm{Film}} \mathrm{cm}^{-1}: 3550,1710,1637,1608,1240,1160,1060$, 990. NMR (in $\mathrm{CDCl}_{3}$ ) $\delta: 0.77(3 \mathrm{H}), 0.90(3 \mathrm{H}), 1.00$ $(3 \mathrm{H}), 1.29(3 \mathrm{H}), 2.00(3 \mathrm{H}), 4.14(2 \mathrm{H}), 5.65(1 \mathrm{H}), 6.07$ $(1 \mathrm{H}), 7.70(1 \mathrm{H})$. Found: C, 72.76; H, 9.94. Calcd. for $\mathrm{C}_{17} \mathrm{H}_{28} \mathrm{O}_{3}: \mathrm{C}, 72.82 ; \mathrm{H}, 10.07 \%$. $\mathrm{XXIX}$, Liquid. 
UV $\lambda_{\max }^{\mathrm{EtOH}} \mathrm{m} \mu(\varepsilon): 268(27,000) . \quad$ IR $\nu_{\max }^{\mathrm{Film}} \mathrm{cm}^{-1}: 3520$, $1710,1615,1240,1160,985$. NMR (in $\mathrm{CDCl}_{3}$ ) $\delta$ : $0.77(3 \mathrm{H}), 0.85(3 \mathrm{H}), 1.02(3 \mathrm{H}), 1.30(3 \mathrm{H}), 2.28(3 \mathrm{H})$, $4.15(2 \mathrm{H}), 5.75(1 \mathrm{H}), 6.05(1 \mathrm{H}), 6.35(1 \mathrm{H})$. Found: $\mathrm{C}$, 73.11; $\mathrm{H}, 10.17$. Calcd. for $\mathrm{C}_{17} \mathrm{H}_{28} \mathrm{O}_{3}: \mathrm{C}, 72.82 ; \mathrm{H}$, $10.07 \%$.

Methyl 5-(1, 2-epoxy-2,6,6-trimethyl-1-cyclohexyl)-3ethyl-cis, trans-2, 4-pentadienoate $(X X X) . \quad 5-(2,6,6$-Trimethyl-1-cyclohexen-1-yl)-4-penten-3-one (900 mg) was subjected to the Wittig reaction and the mixture of the resulting methyl 5-(2,6,6-trimethyl-1-cyclohexen-1-yl)3-ethyl-2, 4-pentadienoates were oxidized with perbenzoic acid to give methyl 5-(1, 2-epoxy-2,6, 6-trimethyl-1-cyclohexyl)-3-ethyl-cis, trans-2, 4-pentadienoate (XXVII) in the manner similar to that for the preparation of $\mathrm{V}$. The over-all yield of XXVII was $17 \%$ Liquid. UV $\lambda_{\max }^{\text {EtoH }} \mathrm{m} \mu(\varepsilon): 268(18,000)$. IR $\nu_{\max }^{\text {Film }} \mathrm{cm}^{-1}$ : $2950,1635,1605,1450,1380,1230,1160,1050,990$. NMR (in $\mathrm{CDCl}_{3}$ ) ô: $0.96(3 \mathrm{H}), 1.08(3 \mathrm{H}), 1.10(3 \mathrm{H})$, $1.15(3 \mathrm{H}), 2.33(2 \mathrm{H}), 3.60(3 \mathrm{H}), 5.52(1 \mathrm{H}), 6.07(1 \mathrm{H})$, $7.35(1 \mathrm{H})$. Found: C, 73.27; H, 9.15. Calcd. for $\mathrm{C}_{17} \mathrm{H}_{26} \mathrm{O}_{3}:$ C, 73.34; $\mathrm{H}, 9.41 \%$.

5-(1, 2-Epoxy-2, 6, 6-trimethyl-1-cyclohexyl)-3-methyl-cis, trans-2, 4-pentadien-1-ol (XXXI). Methyl 5-(1, 2-epoxy2, 6, 6-trimethyl-1-cyclohexyl)-3-methyl-cis, trans-2, 4pentadienoate $(300 \mathrm{mg})$ was treated with an equimolar amount $(40 \mathrm{mg}$ ) of lithium aluminum hydride in tetrahydrofuran $(5 \mathrm{ml})$ at room temperature for $20 \mathrm{hr}$. The reaction mixture was poured into ice-water, acidified with sulfuric acid and extracted with ether. After evaporation of the solvent, the residue was subjected to TLC. Elution with benzene-ethyl acetate ( $85: 15$, $\mathrm{v} / \mathrm{v}$ ) yielded the pentadienol XXXI ( $200 \mathrm{mg}$ ).
Liquid. UV $\nu_{\max }^{\mathrm{EtOH}} \mathrm{m} \mu(\varepsilon): 234(5100), 280(s)(1500)$. IR $\nu_{\max } \mathrm{cm}^{-1}: 3460,1620,1367,1240,1020,980,900$. NMR (in $\mathrm{CDCl}_{3}$ ) $\delta: 0.95(3 \mathrm{H}), 1.10(3 \mathrm{H}), 1.17(3 \mathrm{H})$, $1.87(3 \mathrm{H}), 4.27(2 \mathrm{H}), 5.54(1 \mathrm{H}), 5.92(1 \mathrm{H}), 6.57(1 \mathrm{H})$. Found: C, 75.97; H, 9.98. Calcd. for $\mathrm{C}_{15} \mathrm{H}_{24} \mathrm{O}_{2}: \mathrm{C}$, $76.23 ; \mathrm{H}, 10.24 \%$.

5-(1, 2-Epoxy-2, 6, 6-trimethyl-1-cyclohexyl $)$-3-methyl-2, 4-pentadienonitriles (XXXII and $X X X I I I)$. A mixture of epoxy- $\beta$-ionone $(800 \mathrm{mg}$ ) and cyanomethylenetriphenylphosphorane $(2 \mathrm{~g})$ was treated as described above and applied onto TLC. Elution with benzene-ethyl acetate $(93: 7, \mathrm{v} / \mathrm{v})$ afforded the cis, trans-pentadienonitrile XXXII $(250 \mathrm{mg})$ and its trans, trans-isomer XXXIII (260 mg).

XXXII, Liquid. UV $\lambda_{\max }^{\text {EtOH }} m \mu(\varepsilon): 262(20,700)$. IR $\nu_{\max } \mathrm{cm}^{-1}: 2260,1635,1590,1367,980$. NMR (in $\left.\mathrm{CDCl}_{3}\right) \delta: 0.97(3 \mathrm{H}), 1.12(3 \mathrm{H}), 1.17(3 \mathrm{H}), 2.02(3 \mathrm{H})$, $5.15(1 \mathrm{H}), 6.35(1 \mathrm{H}), 6.80(1 \mathrm{H})$. Found: $\mathrm{C}, 77.74 ; \mathrm{H}$, 9.12; N, 6.01. Calcd. for $\mathrm{C}_{15} \mathrm{H}_{21} \mathrm{NO}$ : $\mathrm{C}, 77.88 ; \mathrm{H}$, 9.15; N, 6.06\%. XXXIII, Liquid. IR $\nu_{\max }^{\text {Film }} \mathrm{cm}^{-1}$ : $2260,1635,1595,1385,980$. Found: C, 77.94; H, 9.27; N, 6.14. Calcd. for $\mathrm{C}_{15} \mathrm{H}_{21} \mathrm{NO}: \mathrm{C}, 77.88 ; \mathrm{H}$, $9.15 ; \mathrm{N}, 6.06 \%$.

Acknowledgements. We wish to express our thanks to Mr. K. Aizawa of this Department for the measurement of IR and NMR spectra and to the members of Analytical Laboratory of this Department for the microanalysis.

After the contribution of this report, we noticed the Netherland patent application by Shell Internationale Research Maatschappi N. V. to disclose the preparation of V, IX and XI [C.A., 72, 898890 (1970)]. 